
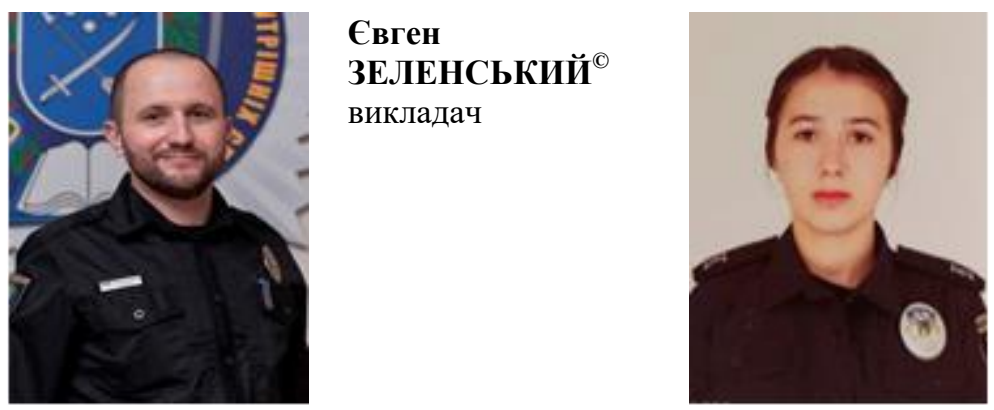

\title{
Марія НОСЕНКО
} ЗЕЛЕНСЬКИЙ викладач курсант

(Дніпропетровський державний університет внутрішніх справ)

\section{ДІЇ ПОЛІЕЙСЬКОГО ПІСЛЯ ЗАСТОСУВАННЯ ТА ВИКОРИСТАННЯ ВОГНЕПАЛЬНОЇ ЗБРОЇ}

Акцентовано увагу на порядку та правомірності дій поліцейських після застосування одного 3 найбільш суворого заходу примусу. Детально проаналізовано нормативно-правові акти, в яких зазначається необхідний перелік та послідовність дій поліцейського. У статті всебічно розглянуто цю проблематику, визначено шляхи вирішення деяких недоліків, які було з'ясовано під час дослідження. Кожен поліцейський, який пройшов відповідну спеціальну підготовку, уповноважений застосувати зброю у виняткових випадках та без попередження, а також ії використати. Однак необхідність правильно виконаних дій після застосування та використання вогнепальної зброї залишаються одним з основних етапів практичної діяльності.

Ключові слова: прачівник полічї̈, вогнепальна зброя, застосування вогнепальної зброї, використання вогнепальної зброї, нормативно-правовий акт.

Постановка проблеми. На сьогодні правовою основою діяльності органів Національної поліції України є Закон України «Про Національну поліцію». Норми цього закону регулюють дії працівників поліції. Законодавець відповідно до цього нормативно-правового акта передбачив усі можливі випадки застосування вогнепальної зброї в діяльності поліцейського. Крім теоретичної частини, працівник поліції повинен знати, як правильно треба діяти в різних ситуаціях, тому законодавець ввів норми, що трактують порядок дій поліцейського після застосування зброї відповідно до певного випадку.

Однак практичні працівники підрозділів Національної поліції не завжди розуміють порядок дій під час застосування заходів примусу. Одним з найбільш суворих заходів примусу вважається застосування вогнепальної зброї. Бувають випадки, коли після застосування чи використання вогнепальної зброї, поліцейські не діють відповідно до закону, тим самим порушують його та наражають на небезпеку пересічних громадян.

Тому порядок дій поліцейських після застосування та використання вогнепальної зброї є актуальним питанням, яке потребує детального розгляду та дослідження для безпеки громадян України та самих поліцейських.

Аналіз публікацій, в яких започатковано вирішення цієї проблеми. Проблематику необхідних дій поліцейських після застосування та використання вогнепальної зброї досліджували у своїх працях такі вчені, як М. Федоров, П. Андрушко, В. Віденко, Л. Чистоклетов, Ю. Баулін, А. Корінець, Л. Попов, Н. Куц, І. Тишкевич, О. Фролов, А. Терещук та ін.

Метою статті є дослідження необхідних дій поліцейських після застосування та використання вогнепальної зброї.

(C) Є. Зеленський, 2021

ORCID iD: https://orcid.org/0000-0002-5345-1513

k_tsp@dduvs.in.ua

(C) М. Носенко, 2021

marian180401@gmail.com 
Виклад основного матеріалу. З'ясовуючи порядок дій поліцейських після застосування вогнепальної зброї, доцільніше буде почати із з'ясування нормативноправової бази, яка надає право поліцейським застосовувати один 3 найбільш суворих заходів примусу. До найголовнішого нормативно- правового акта належить Закон України «Про Національну поліцію». Дія цього закону поширюється на всіх працівників поліції та регламентує підстави застосування та використання вогнепальної зброї. У ст. 46 Закону України «Про Національну поліцію» подано перелік випадків, коли поліцейський має право застосувати вогнепальну зброю у виняткових випадках, без попередження, а також ситуації, що дозволяють поліцейському використати зброю.

У ч. 4 ст. 46 Закону України «Про Національну поліцію» зазначено низку виняткових випадків, які дозволять поліцейському застосовувати вогнепальну зброю, а саме:

1) для відбиття нападу на поліцейського або членів його сім'ї, у випадку загрози їхньому життю чи здоров'ю;

2) для захисту осіб від нападу, що загрожує їхньому життю чи здоров’ю;

3) для звільнення заручників або осіб, яких незаконно позбавлено волі;

4) для відбиття нападу на об'єкти, що перебувають під охороною, конвої, житлові та нежитлові приміщення, а також звільнення таких об’єктів у разі їх захоплення;

5) для затримання особи, яку застали під час вчинення тяжкого або особливо тяжкого злочину і яка намагається втекти;

6) для затримання особи, яка чинить збройний опір, намагається втекти 3-під варти, а також озброєної особи, яка погрожує застосуванням зброї та інших предметів, що загрожують життю і здоров'ю людей та/або поліцейського;

7) для зупинки транспортного засобу шляхом його пошкодження, якщо водій своїми діями створює загрозу життю чи здоров'ю людей та/або поліцейського [1].

Однак законодавець передбачив та доповнив цю статтю додатковими підставами, які дозволяють поліцейському застосовувати вогнепальну зброю без попереднього попередження, цей перелік є вичерпним. Тож у ч. 6 ст. 46 Закону України «Про Національну поліцію» вказано обставини, за яких поліцейський може застосувати вогнепальну зброю без попередження, наприклад:

1) при спробі особи, яку затримує поліцейський із вогнепальною зброєю в руках, наблизитися до нього, скоротивши визначену ним відстань, чи доторкнутися до зброї;

2) у разі збройного нападу, а також у разі раптового нападу із застосуванням бойової техніки, транспортних засобів або інших засобів, що загрожують життю чи здоров'ю людей;

3) якщо особа, затримана або заарештована за вчинення особливо тяжкого чи тяжкого злочину, втікає із застосуванням транспортного засобу;

4) якщо особа чинить збройний опір;

5) для припинення спроби заволодіти вогнепальною зброєю [1].

Проте поліцейські повинні не тільки знати свої права у застосуванні та використанні вогнепальної зброї, а й свої обов'язки. До головних обов'язків, які покладаються на кожного поліцейського, належать ті, що закріплені у ч. 10 ст. 46 вищезазначеного закону. Ця частина статті покладає на поліцейського зобов'язання у вигляді обов'язкового повідомлення свого керівника у письмовій формі після застосування вогнепальної зброї. Поліцейський зобов'язаний власноруч написати рапорт про випадок застосування вогнепальної зброї та вказати всі обставини та підстави його дій.

У ч. 10 ст. 46 Закону України «Про Національну поліцію» зазначено поняття активного застосування вогнепальної зброї та дії працівників поліції після цього. Для уникнення прогалин у розумінні цієї норми доречним буде з'ясувати зміст цього терміна. В Академічному тлумачному словнику з української мови поняття «активне» означає, як здатне вступати в реакцію; як таке, що перебуває у дії; швидко, а поняття «застосування» означає, як використовувати що-небудь [2].

Отже, відповідно до аналізу тлумачення цього терміна, можна вказати, що активне застосування зброї - це дія, під час якої поліцейський швидко використовує зброю. Проте деякі науковці стверджують, що поняття активне застосування зброї варто розуміти як застосування зброї без попередження у випадках, передбачених законом.

Одним із недоліків цього поняття $є$ відсутність його тлумачення у законі, тому законодавець для уникнення можливого неправильного трактування цього терміна та розбіжностей в його розумінні повинен виправити цей нюанс. 
У ч. 10 ст. 46 вище згадуваного закону, зазначено, що поліцейський зобов'язаний негайно повідомити свого керівника про активне застосування вогнепальної зброї. Поліцейський уповноважений активно застосовувати вогнепальну зброю у разі збройного нападу, якщо відвернення чи припинення відповідного нападу неможливо досягнути іншими засобами. Поліцейському заборонено застосовувати вогнепальну зброю в місцях, де може бути завдано шкоди іншим особам, а також у вогненебезпечних та вибухонебезпечних місцях, крім випадків необхідності відбиття нападу або крайньої необхідності [3].

Також при цьому після активного застосування вогнепальної зброї поліцейський повинен не тільки негайно повідомити про це свого керівника, а й в ситуації, коли внаслідок цих дій особі було завдано поранення, терміново надати їй домедичну допомогу.

Проаналізувавши науково-практичний коментар до ст. 46 Закону України «Про Національну поліцію», ми дійшли висновку, що кожен поліцейський, незважаючи на обставини, що склалися внаслідок застосування зброї, повинен будь-якими силами забезпечити безпеку інших осіб і надати невідкладну медичну допомогу потерпілому [3, ст. 220].

Після, або ж у момент надання першої домедичної допомоги, поліцейському необхідно викликати карету швидкої медичної допомоги.

Повертаючись до вище згаданих обов'язків поліцейського, після активного застосування вогнепальної зброї, входить негайне повідомлення свого керівника, а, зі свого боку, керівник зобов'язаний проінформувати центральний орган управління поліції та відповідного прокурора.

На сьогодні випадки застосування вогнепальної зброї трапляються дуже рідко. Однак при цьому бувають ситуації, за яких поліцейський застосовує вогнепальну зброю. Наприклад, нещодавно у місті Чернігові поліцейський зобов'язаний був використати вогнепальну зброю, бо так склалися обставини, а саме вдень до поліції надійшло повідомлення про незаконне проникнення до кафе. Тому поліцейські, прибувши на місце події, побачили розбите вікно та сторонню людину зі зброєю в руках.

Чоловік намагався чинити опір поліцейським та погрожував застосуванням пістолету, тоді один з правоохоронців двічі вистрілив у чоловіка. Перед застосування вогнепальної зброї поліцейський врахував всі ступені ризику та діяв відповідно до ст. 46 Закону України «Про Національну поліцію», а саме п. 6 ч. 4 цієї статті, тобто для затримання особи, яка чинить збройний опір, а також озброєної особи, яка погрожує застосуванням зброї та інших предметів, що загрожують життю і здоров'ю людей та/або поліцейського. Після цього вони надали домедичну допомогу чоловікові та викликали швидку медичну допомогу, проте зараз постраждалий перебуває у комі. Однак за фактом застосування вогнепальної зброї поліцейським проводиться перевірка i розслідування на законність застосування вогнепальної зброї [4]. Тому під час застосування вогнепальної зброї кожний поліцейський повинен розуміти всю відповідальність за свої вчинки та наслідки, які він може спричинити.

Відповідно до ч. 13 ст. 46 Закону України «Про Національну поліцію» поліцейський може використати вогнепальну зброю для подання сигналу тривоги, виклику допоміжних сил або для знешкодження тварини, яка загрожуе життю чи здоров’ю поліцейського та інших осіб [1]. Однак при цьому у ч.10 цієї ж статі не вказано дії працівників поліції після використання зброю. У цьому разі доцільніше було б вказати перелік дій, які поліцейський повинен зробити після використання зброї.

Якщо ж взяти до уваги норму ч. 13 ст. 46 про можливість знешкодження тварини, то варто вказати про дії, які повинен зробити після цього поліцейський. На нашу думку, законодавець повинен доповнити ч. 10 ст. 46 ЗУ «Про Національну поліцію», а саме «Поліцейський зобов'язаний у письмовій формі повідомляти свого керівника про застосування вогнепальної зброї та використання у випадку знешкодження тварини ...». Це доповнення покращило б процес контролювання за діями поліцейських зі зброєю та уникнення зайвих питань щодо подальших дій працівників поліції, наприклад, після знешкодження тварини.

Висновки. Підсумовуючи, варто зауважити, що законодавець надав змогу поліцейським застосовувати та використовувати вогнепальну зброю. Однак із появою прав виникають і обов'язки, які зобов'язують поліцейських у письмовій формі, тобто у вигляді рапорту, повідомляти свого керівника про застосування вогнепальної зброї. 
Тому варто наголосити, що для забезпечення ефективної роботи співробітників поліції вважаємо за необхідне наявність обізнаності кожного поліцейського у сфері застосування вогнепальної зброї. Не менш важливим для службової підготовки під час виконання своїх практичних обов'язків $є$ бездоганне знання нормативно правової бази, яка закріплює право поліцейського на застосування та використання вогнепальної зброї.

Також у разі активного застосування вогнепальної зброї поліцейський зобов'язаний негайно повідомити про це свого керівника, який, зі свого боку, зобов'язаний проінформувати центральний орган управління поліції та відповідного прокурора.

Безпека громадян після застосування вогнепальної зброї покладається на поліцейського, який у разі застосування вогнепальної зброї зобов'язаний надати потерпілому першу медичну допомогу. Під час цього йому необхідно також викликати швидку медичну допомогу.

\section{Список використаних джерел}

1. В Чернигове полицейский применил оружие при задержании. URL : https://www.unn.com.ua/ru/news/1868706-u-chernigovi-politseyskiy-zastosuvav-zbroyu-pid-chaszatrimannya.

2. Про Національну поліцію : Закон України від 02.07.2015 № 580-VIII. Bidомості Верховної Ради України. 2015. № 40-41. Ст. 379.

3. Науково-практичний коментар Закону України «Про Національну поліцію» / кол. авт.; кер. авт. кол. д-р юрид. наук, доц. Т. П. Мінка. Дніпро : Дніпроп. держ. ун-т внутр. справ, 2017. $480 \mathrm{c}$.

4. Словник української мови. Академічний тлумачний словник (1970-1980). URL : http://sum.in.ua/s/zastosovuvaty.

Надійшла до редакиії 14.09.2021

\section{References}

1. V Chernigove politseyskiy primenil oruzhyye pri zaderzhanii [In Chernihiv a policeman used a weapon during arrest] : vebsayt. URL:https://www.unn.com.ua/ru/news/1868706-u-chernigovipolitseyskiy-zastosuvav-zbroyu-pid-chas-zatrimannya. [in Russ.].

2. Pro Natsionalnu politsiyu [On the National Police] : Zakon Ukrayiny vid 02.07.2015 № 580-VIII. Vidomosti Verkhovnoyi Rady Ukrayiny, 2015, no 40-41, art. 379. [in Ukr.].

3. Naukovo-praktychnyi komentar Zakonu Ukrainy «Pro Natsionalnu politsiiu» [Scientific and practical commentary on the Law of Ukraine «On the National Police»] / kol. avt.; ker. avt. kol. d-r yuryd. nauk, dots. T. P. Minka. Dnipro : Dniprop. derzh. un-t vnutr. sprav, 2017. 480 p. [in Ukr.].

4. Slovnyk ukrainskoyi movy. Akademichnyi tlumachnyi slovnyk (1970-1980) [Dictionary of the Ukrainian language. Academic explanatory dictionary (1970-1980)]. URL : http://sum.in.ua//s/zastosovuvatyю [in Ukr.].

\section{ABSTRACT}

Yevhen Zelenskyi, Mariya Nosenko. Actions of the police after the use of firearms. The article is devoted to the use and utilization of firearms by police. The authors emphasizes the order and legality of police actions after the application of one of the most severe coercive measures. The normative-legal acts in which the necessary list and sequence of actions of the police officer after use or application of the firearm are specified are analyzed in detail. The article provides a comprehensive review of this issue, as well as identifies ways to address some of the shortcomings that were identified during the study. Every police officer who has undergone appropriate special training is authorized to use a weapon in exceptional cases and without warning, as well as to use it in the performance of his / her duties.

However, the need for correct action after the use and use of firearms remains one of the main stages of the practical activities of the police. Police officers do not always act correctly after applying one of the most severe coercive measures, which leads to a violation of the requirements established by law, and can sometimes lead to serious consequences or endanger ordinary citizens. In some cases, police officers have shooting skills and know how to act when using a firearm, but after its use, the psychological aspect of the situation plays an important role, which can negatively affect the course of subsequent actions of the police officer. The article considers not only theoretical information, but also the author performed an analysis of cases that occurred with police officers on the need for knowledge in the field of correctness of actions after the use and utilization of firearms.

Keywords: police officer, firearms, use of firearms, legal act, actions of a police officer. 